\title{
Wasfington Hottine
}

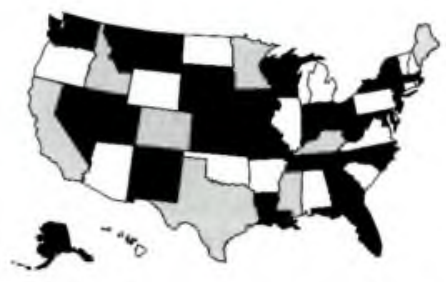

Carol C. Henderson

(202) 547-4440 (ALA0025)

Deputy Director, ALA Washington Office

HEA. With a full hearing room of Library Legislative Day participants in attendance, the House Postsecondary Education Subcommittee held a hearing on April 16 on reauthorization of Higher Education Act Title II library programs. Witnesses were: ALA President Richard M. Dougherty of the University of Michigan School of Information and Library Studies; Legislation Committee Chair E. J. Josey of the University of Pittsburgh School of Library and Information Science; ACRL Government Relations Committee Chair Hiram Davis, Michigan State University Director of Libraries; Legislation Assembly Chair Elaine Albright (also LITA Legislation and Regulation Committee Chair), University of Maine Library Director; and Martha Bowman, Director of Libraries, University of Missouri-Columbia. E. J. Josey also represented the Association for Library and Information Science Education, and Hiram Davis also represented the Association of Research Libraries.

Richard Dougherty provided an overall view of HEA Title II, and concentrated on research needs and the continuing need for the II-B research program. E. J. Josey documented the shortages of minority and other librarians, plus the crisis in the dwindling supply of graduate library school faculty as reasons to continue II-B fellowship assistance. Hiram Davis discussed an ARL study which assessed the effects of the II-C program to strengthen major research libraries, and recommended reauthorization with future grants prompting use of and experimentation in electronic technologies to promote enhanced access to research resources.

Elaine Albright discussed the II-D technology and cooperation grants, a recent and popular program for which the need will be even greater as the National Research and Education Network is implemented. She also told how II-D funds helped make university library resources available to students of the Community College of Maine, a recently developed "campusless" system supporting distance learning at locations throughout the state. Martha Bowman outlined the benefits to Missouri of all parts of the HEA title II programs, testimony of particular interest to ranking minority subcommittee member Tom Coleman (R-MO).

A couple of themes emerged from the question and answer session. One was the concern across all the witnesses for the next generation of professionals in light of the growing shortage of librarians and library faculty members. The other was the implications of the NREN for libraries and education. Witnesses emphasized that libraries should be part of the NREN and that HEA II should help provide resources to make that possible.

Subcommittee members complimented witnesses on an excellent hearing. Chairman Bill Ford (D-MI) said the fact that there was very little repetition showed the witnesses did their homework, and that the large audience showed strong interest. The prepared statements, he concluded, were more than ample to defend reauthorization of these programs for the next decade. 
ture is the foundation upon which the new growth industries can be built."

Issues Briefing Book was written in April 1991 by ten Topics Committees brought together in Washington, D.C., for the express purpose of defining and explaining ten topics that have been most often named during the pre-WHCLIS activities. The topics are: access, networking, technologies, personnel, national information policies, preservation, training of end users, marketing, services/programs, and governance.

Topics Committee members consolidated 1,100 recommendations received from state and terri- tory pre-WCHLIS events into 150 suggested solutions. The recommendations are preserved and indexed by their originating state or territory. Issues Briefing Book will be published in early June and will be distributed to delegates before the White House Conference.

Copies of Discussion Papers and Issues Briefing Book may be requested from the office of the White House Conference on Library and Information Services, 1991, 1111 8th Street, N.W., Suite 302, Washington DC 20036, Telephone (202) 2545100 .

(Washington Hotline con't from page 377)

On April 8, ALA and ARL jointly submitted specific legislative amendments and rationale to the House subcommittee as requested by its chair and ranking minority member. Recommendations were based on the work of the ACRL Government Relations Committee. The American Council on Education and 11 other higher education associations endorsed the ALA/ARL recommendations for HEA II.

The recommendations proposed: reauthorization of HEA Title II with a new name, "Academic Libraries in an Electronic Networked Environment," to reflect the changing roles of libraries and librarians in response to new ways of providing information; deletion of the current II-A grants for college library resources (unfunded since FY 1983) and replacement with an updated II-D technology assistance program; and continuation with minor amendments of the IIB program of research and education and the II-C grants to major research libraries.

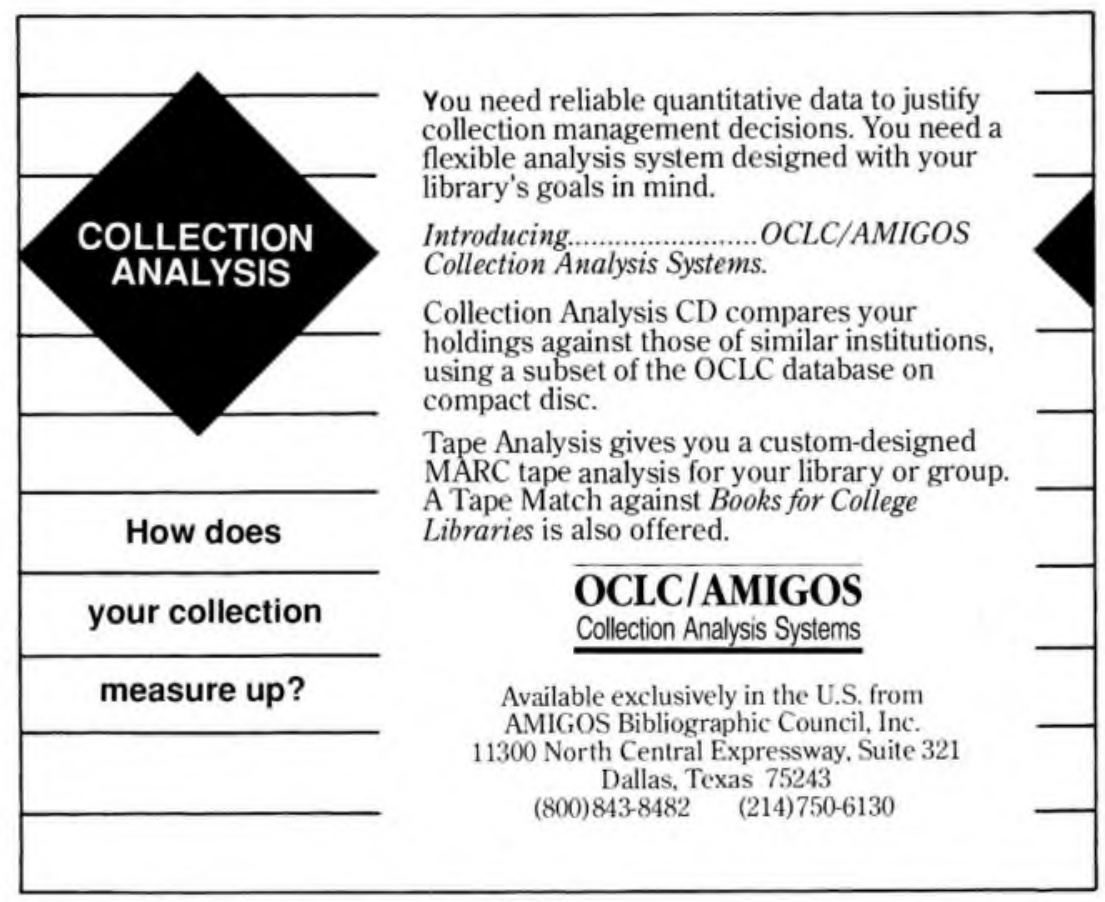

